\title{
THE DEVOLVED PARTY SYSTEMS OF THE UNITED KINGDOM
}

\author{
Sub-national Variations from the National Model
}

Robert E. Bohrer II and Glen S. Krutz

\begin{abstract}
In this article we examine the emerging party systems of the devolved environments, with an eye toward shedding light on the factors that influence the number of parties in a system where parties are already mobilized but the institutional context is new. Our findings demonstrate that electoral rules have an independent effect on the number of parties. More specifically, the use of proportional representation has increased the number of parties. In addition, two social cleavage structure factors appear to affect the design of the party system: class and centerperiphery. All of these forces lead to a more complex governing arrangement in the devolved settings than that of the United Kingdom.
\end{abstract}

KEY WORDS - cleavages - devolution - mixed-member proportional representation - plurality

\section{Introduction}

The end of the twentieth century marked a shift in the political structure of the United Kingdom (UK). In the summer of 1999, the Scottish Parliament convened for the first time in nearly 300 years, while similar institutions opened in Wales and Northern Ireland. While emanating from Westminster, the devolved institutions varied a great deal from both the British model of parliament as well as from one another, though all three continued to remain subject, to varying extents, to the functioning of the British system. The advent of sub-national government in the UK offers numerous opportunities for studying the effects of varying types of institutions, the expansion of issue agendas and the dynamics of multi-level governance. In this article, we compare and contrast the emerging party systems of the devolved environments with those at the national level, with an eye toward shedding 
light on the factors that influence the number of parties in a system and the effects of the party system on the cabinet level. While these systems are not 'new' in the sense of newly democratized countries, they offer insight into the effects of a new context and rules in an existing democracy.

The distinctions between the national and sub-national levels of the UK offer an unusual opportunity for a quasi-experimental examination of the factors that influence the formation and effects of party systems. While British parliamentary elections are conducted using plurality electoral laws, the devolved systems deviate from this pattern, using mixed-member proportional (MMP) representation in Scotland and Wales and the singletransferable vote (STV) in Northern Ireland. Moreover, the devolved settings offer a contrast in the types of party systems and various cleavage structures. This begs the question of whether the distinct party systems at the sub-national level are a result of the changes in electoral laws or different cleavage patterns operating at the sub-national level. While the debate over the relative impact of electoral laws versus social cleavages on party systems is nothing new, the devolved systems shed new light on this old controversy. It is to this controversy that we now turn.

\section{Party System Determinants and Party System Change}

As important linkage institutions, political parties and party systems and the factors that influence their development and operation have received a wealth of attention from scholars (for a review, see Lijphart, 1994a). Existing empirical and theoretical work concentrates primarily on the role of two factors - electoral rules and social cleavages - in shaping the formation and structure of party systems. Although these two factors dominate the discussion of party system determinants, they are rarely accorded equal weight by the same author. In essence, these two factors represent separate paradigms competing to explain both the formation and continuity of party systems in advanced industrial democracies. As is shown below, separately neither explanation is wholly satisfactory in explaining either the development or the continuity of party systems.

\section{Electoral Rules, Cleavage Patterns and Party Systems}

The lineage of electoral rules as instrumental in determining party system attributes can be traced back at least to F. A. Hermens (1941), who claimed that proportional representation (PR) led to a proliferation of political parties, unstable government and political extremism. Based on his analysis of the adoption of PR in Weimar Germany and Italy, he argued that the permissive nature of such electoral rules dispersed power and allowed extremist Nazi and fascist groups to gain representation in parliament and eventually take control of both governments. 
Similarly, Maurice Duverger (1954) posited that electoral laws are an essential component in party system formation. According to his theory, plurality electoral laws lead to two-party systems and political stability through single-party majority governments (Duverger's Law), whereas PR causes fragmentation of parties and results in unstable coalition governments (Duverger's hypothesis). Despite some exceptions (notably, Canada at the national level), Duverger's argument essentially states that electoral rules play a dominant role in shaping the party system and has received both a great deal of support (Riker, 1982; Sartori, 1994; Taagepera and Shugart, 1989) and criticism (Blondel, 1972; Lipson, 1959).

The most comprehensive theoretical challenge to the impact of electoral systems on party systems was issued by Seymour Lipset and Stein Rokkan (1967), who argued that cleavage structures were responsible for party system characteristics. Lipset and Rokkan posited that deep-seated cleavages determined the balance of power in the political system. Electoral rules emerged as a result of the underlying cleavages and power distributions. Hence, party system characteristics were determined by the underlying cleavage structures; electoral rules simply mirrored such cleavages. In what has come to be known as the 'frozen party thesis', Lipset and Rokkan go on to argue that as industrialization became firmly implanted through near universal suffrage, Western party systems were in effect 'frozen' along the cleavage structures in place in the early part of the twentieth century. This thesis is echoed in Luebbert's (1991) explanation of regime types of interwar Europe.

Lipset and Rokkan attribute these cleavage structures to two major revolutions in Western Europe: the National Revolution and the Industrial Revolution. The former concerned the rise of the nation-state and the process of nation-building. As this process progressed, two primary cleavages - center versus periphery and Church versus state - emerged. During the latter revolution, two additional cleavages - landed interests versus industrialists and workers versus owners - became relevant as well (Lipset and Rokkan, 1967). With some relatively minor exceptions, Lipset and Rokkan argued that since the advent of universal or near universal suffrage at the beginning of the twentieth century no fundamental shifts had occurred in the party systems of Western Europe, and hence party systems in the 1960s looked remarkably similar to those found in the 1920 s. $^{1}$

More recent work has challenged the social determinism school and found it lacking; party systems have experienced changes which Lipset and Rokkan ruled out (Shamir, 1984). As a result, theoretical work has come full circle, and once again points to the importance of electoral laws in shaping party system characteristics. The resurgence of interest in political institutions, dubbed the 'New Institutionalism' (March and Olsen, 1984), has been at the forefront of renewed interest in the consequences of electoral laws. Building from Rae's (1967) seminal work finding that district magnitude was critical in determining the effective number of parties and level of 
fractionalization in a system, scholars have attempted to refine the relationship between electoral laws and party systems.

Increases in data availability have led to more cross-national comparisons of the effects of electoral rules on parties and party systems. Taagepera and Shugart (1989) offer impressive statistical evidence that district magnitude plays an important part in determining vote to seat disproportionality. In addition, they point out a statistical relationship between high district magnitudes and greater numbers of effective parties. Similarly, Lijphart (1994) finds that electoral systems play a key role in shaping party systems.

\section{'Thawed' Party Systems?}

More than three decades have passed since Lipset and Rokkan's assertion of frozen party systems, and since that time a great deal of attention has been placed on the entry of new parties into the electoral arena. Much of the evidence of party system change is centered around the work of Mogens Pedersen's (1979) seminal article on patterns of electoral volatility in postwar European democracies. This article introduced the Pedersen index of volatility, a measure now widely used as an indicator of shifts in party support among the electorate (see Mair, 1997). Using this index, a trend toward increasingly volatile electorates has emerged.

Aggregate level studies have revealed some interesting and at times contradictory results. In general, findings show that party systems are becoming more fluid and that European electorates are becoming more volatile and display less loyalty to parties than in the past (see Ersson and Lane, 1998; Pedersen, 1979; Shamir, 1984). In particular, studies of voter volatility have shown steady increases across the European electorates (Bohrer and Tan, 2000). As Ersson and Lane (1998: 35) note, '[t]he evidence from several sources is that electoral instability is up in the late twentieth century in Western Europe. The voters are no longer frozen in established commitments toward political parties'.

Along the same lines, there has been some progress in reconciling the electoral laws versus societal cleavages arguments among scholars of party systems. Bartolini and Mair (1990) argue that effects of the electoral system and social cleavages both play a role in determining the shape of a country's party system. Similarly, Gary Cox (1997) concludes, as do Ordeshook and Shvetsova (1994), that the effective number of political parties is dependent on both the level of social heterogeneity and the electoral rules in place. As Cox (1997: 221) puts it, 'a polity can tend toward bipartism either because it has a strong electoral system or because it has few cleavages. Multipartism arises as the joint product of many exploitable cleavages and a permissive electoral system'.

While there is little doubt of increasing fluctuations in voting patterns across Western Europe, there is no consensus on the extent of this change. Scholars who have taken note of the thawing of the frozen party systems 
have pointed to the rise of 'New Politics' issues of the right and the left as the major source of change (Betz, 1993; Kitschelt, 1997). Many such explanations of this change rely on Inglehart's $(1971,1990)$ conception of a 'post-materialist' culture becoming dominant among the generation coming of age in the prosperous times following World War II. However, the alleged effect of this new dimension has not been uniform across the advanced industrial democracies; countries with similar electoral laws and cleavage structures vary in the extent to which these forces have been observed (see Dalton, 1988). Similarly, even when admitting change in the vote shares received by parties and the emergence of new parties, some scholars still question whether these changes represent a fundamental shift in the party system. For example, Kitschelt (1997) notes that, despite the collapse of the Italian party system in 1994 and the switch from a list-PR system to MMP representation, the initial distributions of power in Italy were not remarkably different in terms of the cleavages represented from those preceding them. Similarly, Mair (1997) underscores that instances of inter-area volatility - shifts across party families - are much less common and muted, and he cautions against placing too much emphasis on more typical intra-area volatility.

\section{Evaluating the Devolved Party Systems of the United Kingdom}

A review of the literature on the formation and change in party systems shows disagreement on the causes of formation and at least some uncertainty concerning the forces of change. All existing research concentrates on either the national level or the effects of the electoral system at the district level, however, and devolution in the UK allows us to examine several new aspects concerning party systems and prompts several questions. First, do the party systems in the devolved assemblies simply mirror those for each of the regions as subunits of the already mobilized system of the UK? Second, are differences between the UK and sub-national party systems the result of underlying cleavage structures, the distinct electoral laws employed for devolved elections or the emergence of new cleavages such as postmaterialism? Third, what, if any, effects have party system characteristics had on government formation in the devolved systems? Finally, what effect has the context of devolution had on the political parties themselves?

Following Pedersen's (1979) template, we examine three levels of party system analysis: the electoral level, the parliament and government level and the party organization level, with most of our emphasis on the first two issues. To evaluate the changes in party systems from the UK level to the sub-national level, we examine the results of the 1992, 1997 and 2001 elections to the House of Commons from the Scottish, Welsh and Northern Irish subunits (i.e. isolating the election results for those regions). These 
results are then compared to those from the 1998 National Assembly election in Northern Ireland and elections to the National Assembly for Wales and the Scottish Parliament held in 1999 as well as the 2003 devolved elections in all three.

Turning to the electoral level, Table 1 compares the election results from the 1992-2001 UK elections to the initial elections held for the devolved assemblies. From the information contained in this table, it is clear that the elections to the devolved institutions resulted in larger party systems with vote and seat shares more evenly distributed. In both Scotland and Northern Ireland, additional parties received representation, and in all three systems the results were much more balanced in terms of the seat percentage awarded, as the level of disproportionality was reduced markedly (creating

Table 1. Comparing disproportionality in Scotland, Wales and Northern Ireland under first-past-the-post Westminster elections and devolved assemblies

\begin{tabular}{|c|c|c|c|c|c|c|c|c|c|}
\hline & \multicolumn{3}{|c|}{$\begin{array}{l}\text { Averages, 1992, } 1997 \\
\text { and } 2001 \text { UK elections }\end{array}$} & \multicolumn{6}{|c|}{ Devolved elections } \\
\hline & Vote\% & Seat $\%$ & Diff. & Vote\% & Seat $\%$ & Diff. & Vote\% & Seat $\%$ & Diff. \\
\hline Scotland & & & & & 1999 & & & 2003 & \\
\hline Labour & 42.8 & 74.6 & +31.8 & 33.6 & 43.4 & +9.8 & 29.3 & 38.8 & +9.5 \\
\hline SNP & 21.2 & 6.5 & -14.7 & 27.3 & 27.1 & -0.2 & 20.9 & 20.9 & 0.0 \\
\hline Conservative & 19.6 & 5.6 & -14.0 & 15.4 & 14.0 & -1.4 & 15.5 & 14.0 & -1.5 \\
\hline Lib-Dem & 14.1 & 13.4 & -0.7 & 12.4 & 13.2 & +0.8 & 11.8 & 13.2 & +1.4 \\
\hline Green & - & - & - & 3.6 & 0.8 & -2.8 & 6.7 & 5.4 & -1.3 \\
\hline Scot. Socialist & - & - & - & 2.0 & 0.8 & -1.2 & 6.9 & 4.7 & -2.2 \\
\hline Wales & & & & & 1999 & & & 2003 & \\
\hline Labour & 50.9 & 80.4 & +29.5 & 35.5 & 46.7 & +11.2 & 36.6 & 50.0 & +13.4 \\
\hline Conservative & 23.1 & 5.3 & -17.8 & 16.5 & 15.0 & -1.5 & 19.2 & 18.3 & -0.9 \\
\hline Plaid Cymru & 10.9 & 10.2 & -0.7 & 30.6 & 28.8 & -1.8 & 19.7 & 20.0 & +0.8 \\
\hline Lib-Dem & 12.9 & 4.2 & -8.7 & 12.5 & 10.0 & -2.5 & 12.7 & 10.0 & -2.7 \\
\hline Northern Ireland & & & & & 1998 & & & 2003 & \\
\hline UUP & 31.3 & 47.3 & +16.0 & 21.1 & 25.9 & +4.8 & 22.7 & 25.0 & +2.3 \\
\hline SDLP & 22.9 & 19.0 & -3.9 & 22.0 & 22.2 & +0.2 & 17.0 & 16.7 & -0.3 \\
\hline DUP & 16.4 & 18.8 & +2.4 & 18.0 & 18.5 & +0.5 & 25.7 & 27.8 & +2.1 \\
\hline Sinn Fein & 15.9 & 11.1 & -4.8 & 17.7 & 16.7 & -1.0 & 23.5 & 22.2 & -1.3 \\
\hline $\mathrm{AP}$ & - & - & - & 6.5 & 5.6 & -0.9 & 3.7 & 5.6 & +1.9 \\
\hline United Kingdom & & 1992 & & & 1997 & & & 2001 & \\
\hline Labour & 34.4 & 40.0 & +5.6 & 43.3 & 63.6 & +20.3 & 40.7 & 62.7 & +22.0 \\
\hline Conservative & 41.9 & 49.6 & +7.7 & 30.6 & 25.0 & -5.6 & 31.7 & 25.2 & -6.5 \\
\hline Lib-Dem & 17.8 & 3.0 & -14.8 & 16.7 & 7.0 & -9.7 & 18.3 & 7.9 & -10.4 \\
\hline SNP & 1.9 & 0.5 & -1.4 & 2.0 & 0.9 & -1.1 & 1.8 & 0.8 & -1.0 \\
\hline UUP & 0.8 & 1.4 & +0.6 & 0.8 & 1.5 & +0.7 & 0.8 & 0.9 & +0.1 \\
\hline DUP & 0.3 & 0.5 & +0.2 & 0.3 & 0.3 & 0.0 & 0.7 & 0.8 & +0.1 \\
\hline Sinn Fein & - & - & - & 0.4 & 0.3 & -0.1 & 0.7 & 0.6 & -0.1 \\
\hline Plaid Cymru & 0.5 & 0.6 & +0.1 & 0.5 & 0.6 & +0.1 & 0.7 & 0.6 & -0.1 \\
\hline SDLP & 0.5 & 0.6 & +0.1 & 0.6 & 0.5 & -0.1 & 0.6 & 0.5 & -0.1 \\
\hline
\end{tabular}


more fractionalized systems at both the elective and parliamentary levels) as a result of the implementation of PR in the devolved settings.

While established parties still commanded most of the votes and seats in the devolved elections, the relative strength of the parties shifted a great deal. In both Scotland and Wales the Labour Party's dominant position in UK elections was eroded. Though Labour remained the largest party under devolution, it no longer commanded over three-quarters of the seats and in fact was unable to gain a majority of the seats in either of the first two devolved elections in Scotland and Wales. The results in Northern Ireland show that in both UK and devolved elections, the party system in Northern Ireland is quite distinct from the rest of the UK. While Scotland and Wales both have strong nationalist parties in the Scottish National Party (SNP) and Plaid Cymru (PC), both systems have the 'traditional' UK parties: Labour, Conservative and Liberal Democrats. By contrast, in Northern Ireland none of these parties even contest elections - a subject we discuss in more detail below.

Although useful, these aggregate data do not provide an adequate test for the disputes outlined above. In Table 2, more refined measures of party system characteristics are presented. Based on these data, it is obvious that devolution is associated with more effective political parties, both at the elective (votes) and parliamentary (seats) levels. ${ }^{2}$ In fact, the increase in both of these numbers is striking. The effective number of electoral parties provides a glimpse into the 'psychological' influence of electoral laws - in other words, the strategic behavior by voters to avoid wasting votes on parties that will not receive representation in parliament. It is clear from these results that voters in the devolved elections understood that the prospect of a wasted vote was less likely under the PR systems used in devolved elections. As a result of this increased distribution of seats at the level of the electorate and the lower mechanical reductions in vote to seat translations, the party systems in the devolved assemblies more than doubled (on average) from the plurality elections for the House of Commons. ${ }^{3}$

Hence, the party systems in all three devolved settings diverged from the British norm of two-party or two-and-a-half-party politics, and, particularly in Scotland and Wales, diverged from national election results within the same region. The effective number of parliamentary parties dramatically increased in all three contexts and in none of the three did a single party obtain a majority of the assembly seats - a sharp contrast to the 'manufactured majorities' that typify elections to the House of Commons. In addition, it is interesting to note the uniform pattern of increase in both elective and parliamentary parties across the three cases - while the effective number of parties increases across the board, Wales still has the fewest number of parties, Northern Ireland the greatest.

Based on these findings, we can safely conclude that the devolved party systems all fit into the multiparty category. While this may be a result of the 
Table 2. Party system characteristics in the United Kingdom: devolved versus UK elections

Effective no. of elective parties

Increase UK

to devolved

UK elections (1992, 1997 and 2001)

Devolved

Scotland

Wales

Northern Ireland

Mean

$\begin{array}{lllll} & 1999 & 2003 & \text { Avg. } & \\ 3.44 & 4.55 & 5.66 & 5.11 & 48.5 \% \\ 2.91 & 3.77 & 4.43 & 4.10 & 40.0 \% \\ 4.48 & 6.00 & 4.92 & 5.46 & 21.9 \% \\ 3.61 & 4.77 & 5.00 & 4.89 & 35.5 \%\end{array}$

Effective no. of parliamentary parties

\begin{tabular}{lrrrrr}
\hline Scotland & 1.72 & 3.33 & 4.24 & 3.79 & $120.3 \%$ \\
Wales & 1.45 & 3.02 & 3.00 & 3.01 & $107.6 \%$ \\
Northern Ireland & 2.65 & 5.40 & 4.54 & 4.97 & $87.5 \%$ \\
$\quad$ Mean & 1.94 & 3.92 & 3.93 & 3.92 & $102.1 \%$ \\
\hline
\end{tabular}

change in electoral rules, and hence could lend support to the argument that electoral rules shape party systems, one could also argue that devolution has simply changed the context and hence politicized cleavages that were previously subsumed in the broader context of British politics. These cleavages are akin to E. E. Schattschneider's (1960: Ch. 4) subordinate conflicts that are marginalized in the 'conflict of conflicts'. In the devolved context, these conflicts lose their subordinate status and the result of this increased saliency for regional matters leads to an increase in the number of political parties.

Fortunately, the adoption of MMP representation in Scotland and Wales allows us to evaluate at least part of this controversy. ${ }^{4}$ Under the MMP arrangements, seats are divided into single-member constituencies ( 73 of the 129 seats in the Scottish Parliament and 40 of the 60 seats in the National Assembly for Wales) and party list seats. Voters cast two votes: one for a constituent representative and one for a party list. Hence, the system incorporates plurality aspects and proportional elements (the list seats are used to 'top up' or compensate for disproportionalities resulting from the single-member districts). By comparing the single-member plurality districts in the devolved elections with the results from House of Commons elections, we can determine whether it is the mechanics of the electoral system or the emergence of previously marginalized cleavages that is responsible for the increased number of parties. If electoral rules are driving the increase, we would expect the single-member constituencies in the devolved systems to yield roughly the same results as those for UK elections; if cleavages are responsible for the increased number of parties, we would expect to see evidence of this in the results from the devolved single-member districts.

Table 3 displays the effective number of parties resulting from the singlemember districts of the devolved elections and the effective number of 
parties under the UK system. While in both cases the effective number of parliamentary parties increased, the increase was negligible in Scotland but more substantial in Wales. This could indicate that at least in Wales the cleavage pattern could have pushed up the number of parties. It is interesting to note that despite the increases in both Scotland and Wales, both contexts are two-party systems when the single-member constituency seats are isolated. Hence, they conform to Duverger's Law. In addition, the second part of Table 3 shows that the single-member constituency seats yield much smaller numbers of political parties than the overall outcome. When the PR list seats are included, the total number of effective parliamentary parties increases by over 88 percent in Scotland and over 64 percent in Wales. Clearly, the limited changes between the devolved and national results in the single-member districts indicate that there is a strong relationship between the electoral laws and the number of parties in the party system.

Although there is strong evidence for the role of electoral laws in shaping the party systems of the devolved areas, it is reasonable to assume that the change in venue - from the national to the sub-national level - also influenced the party systems. For example, while in Wales the Conservatives tend to run second to Labour in UK elections, the Welsh National Party Plaid Cymru - has emerged as the second party under devolution, leaving the Tories a distant third. Hence, the move from the national to the subnational level seemed to increase the importance of the issues of the nationalist parties, as in both Scotland and Wales these parties headed the opposition. To evaluate the impact of the change in venue on the party systems, we now turn to more qualitative evidence.

Table 3. Electoral rules vs. cleavages: comparing the single-member districts in MMP to UK election results in Scotland and Wales

\begin{tabular}{|c|c|c|c|c|c|}
\hline \multicolumn{6}{|c|}{$\begin{array}{l}\text { Effective no. of parliamentary parties - comparison with UK elections } \\
\qquad \text { SMP } \\
\text { Single-member }\end{array}$} \\
\hline & 1999 & 2003 & Avg. & 1992-2001 & dev. to UK \\
\hline Scotland & 1.77 & 2.24 & 2.01 & 1.72 & $+16.9 \%$ \\
\hline Wales & 1.95 & 1.71 & 1.83 & 1.45 & $+26.2 \%$ \\
\hline
\end{tabular}

Effective no. of parliamentary parties - comparison with overall devolved outcomes MMP Total

Single-member devolved Diff.

\begin{tabular}{llll} 
Scotland & 2.01 & 3.79 & $+88.6 \%$ \\
Wales & 1.83 & 3.01 & $+64.5 \%$ \\
\hline
\end{tabular}




\section{Cleavages and Party Systems at the Sub-national Level}

The party systems of the three sub-national entities in the UK are all distinct from one another and from that at the national level. At the national level, the primary conflict is socio-economic, with the Labour Party representing more of the urban working class, while the Conservatives are associated with rural and more upper-class issues. The two parties also have divergent positions on issues such as the UK's role in the European Union, but the predominant issue tends to be class (Butler, 1996). By contrast, in each of the devolved regions there are issues that, because they represent a small proportion of the UK's population, tend to be ignored at the national level. In fact, the distinct natures of each of the devolved regions were at the heart of the rationale for establishing sub-national governance. Let us now turn to an analysis of the three systems individually.

\section{Northern Ireland}

Table 1 shows how the party system in Northern Ireland is distinct from any other part of the UK. Owing to the partition of Ireland in 1921, the six counties of Ulster where Unionists (primarily Protestants) wished to remain part of the UK were granted Home Rule but remained within the UK. Under Home Rule, powers were devolved to a parliament eventually located in Stormont, giving Northern Ireland a level of self-rule. This initial experiment in devolution ultimately proved disastrous in Northern Ireland, in part because the majoritarian nature of the institutions excluded Catholics and ensured Protestant dominance (Bohrer, 2001). The party system that emerged centered principally along sectarian grounds and the proper position for the province - the Ulster Unionist Party (UUP) and Democratic Unionist Party (DUP) are predominantly Protestant and wish to remain within the UK, while Sinn Fein (SF) and the Social Democratic and Labour Party (SDLP) are predominantly Catholic and seek, to different degrees, a unified Ireland. The Good Friday Agreement which provides for the Northern Ireland Assembly has also played into the cleavage structure: the UUP, SDLP and Alliance Party (AP) all support the continuation of the agreement; Sinn Fein is supportive of the agreement, but its ties to the Provisional IRA cause some consternation about how genuine and complete this support is. Finally, the DUP seeks a complete overhaul of the peace agreement.

Class is also a factor in Northern Ireland's political spectrum (and conflict), with the DUP and Sinn Fein drawing support from the lower socioeconomic strata, but this issue is so intertwined with the religious loyalistseparatist dimension that it is essentially impossible to separate them. In effect, Northern Ireland represents a classic case of reinforcing cleavages. Given the depth of the differences and the open conflict that has characterized 'The Troubles', it is not surprising that this system is the most 
Table 4. Comparing party system characteristics in Northern Ireland, 1992-2001

\begin{tabular}{|c|c|c|c|c|c|}
\hline \multirow[b]{3}{*}{ Party system characteristics } & \multicolumn{5}{|c|}{ Election year } \\
\hline & \multicolumn{3}{|c|}{ National } & \multicolumn{2}{|c|}{ Devolved } \\
\hline & 1992 & 1997 & 2001 & 1998 & 2003 \\
\hline Fractionalization (votes) & 0.79 & 0.78 & 0.78 & 0.83 & 0.80 \\
\hline Fractionalization (seats) & 0.63 & 0.33 & 0.73 & 0.81 & 0.78 \\
\hline Effective parties (votes) & 4.7 & 4.23 & 4.54 & 6.0 & 4.92 \\
\hline Effective parties (seats) & 2.71 & 1.49 & 3.76 & 5.4 & 4.54 \\
\hline \multicolumn{6}{|l|}{ Largest bonus } \\
\hline (\%seats - \%votes) & +18.4 & +22.9 & +6.6 & +4.6 & +2.3 \\
\hline Beneficiary & UUP & UUP & UUP & UUP & UUP \\
\hline \multicolumn{6}{|l|}{ Largest penalty } \\
\hline (\%seats - \%votes) & -9.97 & -7.45 & -4.3 & -1.1 & -1.3 \\
\hline Penalized & Sinn Fein & SDLP & SDLP & SDLP & Sinn Fein \\
\hline
\end{tabular}

fractionalized of the three devolved bodies. Table 4 displays several relevant party system characteristics for Northern Ireland, with a comparison of the 1992, 1997 and 2001 UK elections in the region for comparison. What is striking about the results is that in contrast to the previous experience with Home Rule (1921-1972) the dominance of the UUP was ended with the move to a devolved institution.

Taken with the results contained in Table 1, it is clear that local interests are of primary concern in Northern Ireland regardless of the electoral context. Also noteworthy, however, is the fact that since the initial elections to the Northern Ireland Assembly the distribution of power within both the Unionist and Nationalist communities has shifted to the more extreme parties (the DUP and Sinn Fein, respectively). Moreover, this shift has filtered into the national elections as both the DUP and Sinn Fein made substantial gains in the 2001 UK elections.

\section{Scotland and Wales}

Politics in Scotland has been referred to as 'British with a difference' (McAllister and Rose, 1984: 136), but important variations do exist between Scotland and Westminster (Brown et al., 1999). One minor, but symbolically important, difference is the names of the parties. For example, the Conservative Party is the 'Scottish Conservative and Unionist Party'. This nominal change intimates the most important dimension that is present at the Scottish level but relatively mild at the national level: independence. Among the national parties - Labour, Conservative and Liberal Democrats - there are differences on this issue. The official Conservative Party stance was against devolution, though it now accepts this as a fait accompli (Interview with MSP and Conservative and Unionist Parliamentary Leader 
David McLetchie, June 2000). The Labour Party initiated the move toward devolution and hence follows a continuation of the present arrangements as the best path for Scotland, while the Liberal Democrats are in favor of a federal state. Thus, the three major national parties all have different views on the issue of independence or autonomy for Scotland. The Scottish National Party (SNP), Scottish Socialist Party and Greens, all three of which are in favor of an independent Scotland, oppose these three. Table 5 displays the party system characteristics of Scotland.

Cleavages in the Welsh party system mirror those in Scotland, with some relatively minor differences. One such difference concerns the nationalist Plaid Cymru, which has recently dropped the demand for Welsh independence, though it is unclear what level of autonomy the party envisions. Like the SNP in Scotland, Plaid Cymru emerged from the devolved elections as the second largest party, and here again the Conservatives slipped to third. Another similarity with Scotland is the end of dominance for the Labour Party. While in the 1992-2001 elections to the House of Commons Labour controlled over 80 percent of the seats from Wales, under the devolved arrangements Labour was reduced to less than a majority of the seats in the new assembly. As Table 6 shows, this resulted in increased party system fragmentation, though primarily at the parliamentary level.

It is interesting to note that in all three devolved systems the main cleavage that initially emerges is the center-periphery cleavage that Lipset and Rokkan (1967) associate with the National Revolution. Although all three of these regions were absorbed by England into the UK long ago, the presence of large nationalist parties in the devolved settings contrasts not only with overall UK results, but is also increased from the subunits of Scotland, Wales and Northern Ireland for elections to the House of Commons.

Table 5. Comparing party system characteristics in Scotland, 1992-2001

\begin{tabular}{|c|c|c|c|c|c|}
\hline \multirow[b]{3}{*}{ Party system characteristics } & \multicolumn{5}{|c|}{ Election year } \\
\hline & \multicolumn{3}{|c|}{ National } & \multicolumn{2}{|c|}{ Devolved } \\
\hline & 1992 & 1997 & 2001 & 1999 & 2003 \\
\hline Fractionalization (votes) & 0.719 & 0.692 & 0.716 & 0.78 & 0.82 \\
\hline Fractionalization (seats) & 0.495 & 0.369 & 0.370 & 0.70 & 0.76 \\
\hline Effective parties (votes) & 3.56 & 3.25 & 3.5 & 4.55 & 5.66 \\
\hline Effective parties (seats) & 1.98 & 1.58 & 1.99 & 3.33 & 4.24 \\
\hline \multicolumn{6}{|l|}{ Largest bonus } \\
\hline (\%seats - \%votes) & +29.06 & +32.17 & +33.9 & +9.8 & +9.5 \\
\hline Beneficiary & Labour & Labour & Labour & Labour & Labour \\
\hline \multicolumn{6}{|l|}{ Largest penalty } \\
\hline (\%seats - \%votes) & -17.30 & -17.50 & -14.2 & -2.8 & -2.2 \\
\hline Penalized & SNP & Cons. & Cons. & Green & Soc. \\
\hline
\end{tabular}


Table 6. Comparing party system characteristics in Wales, 1992-2001

\begin{tabular}{|c|c|c|c|c|c|}
\hline \multirow[b]{3}{*}{ Party system characteristics } & \multicolumn{5}{|c|}{ Election year } \\
\hline & \multicolumn{3}{|c|}{ National } & \multicolumn{2}{|c|}{ Devolved } \\
\hline & 1992 & 1997 & 2001 & 1999 & 2003 \\
\hline Fractionalization (votes) & 0.65 & 0.64 & 0.68 & 0.74 & 0.77 \\
\hline Fractionalization (seats) & 0.39 & 0.27 & 0.27 & 0.67 & 0.67 \\
\hline Effective parties (votes) & 2.86 & 2.75 & 3.12 & 3.77 & 4.43 \\
\hline Effective parties (seats) & 1.64 & 1.36 & 1.36 & 3.02 & 3.00 \\
\hline \multicolumn{6}{|l|}{ Largest bonus } \\
\hline (\%seats - \%votes) & +21.6 & +30.28 & +36.4 & +11.2 & +13.4 \\
\hline Beneficiary & Labour & Labour & Labour & Labour & Labour \\
\hline \multicolumn{6}{|l|}{ Largest penalty } \\
\hline (\%seats - \%votes) & -12.8 & -19.59 & -21.0 & -2.5 & -2.7 \\
\hline Penalized & Cons. & Cons. & Cons. & Lib-Dem & Lib-Dem \\
\hline
\end{tabular}

Also worthy of note is the lack of influence of post-materialism in any of the initial elections to the devolved bodies. While Robin Harper's election to the Scottish Parliament made him the first Green elected to any office above the local level, he was the lone representative of such a cleavage at the national or sub-national level in the UK. However, in 2003 the Scottish Greens were much more successful, moving from one to seven seats. Still, other issues dwarfed this 'New Politics' cleavage. In historical terms, the devolution of authority to sub-national units has given new life to cleavages associated with the oldest revolution, while the most recent 'culture shift' initially played a very marginal role in shaping the devolved party systems. ${ }^{5}$

To review, both electoral laws and cleavage structures have been important in shaping the devolved party systems. The implementation of PR electoral laws resulted in multiparty systems ranging from three to five effective parliamentary parties, all in contrast to that found at the UK level. Moreover, devolution created space (which was accommodated by more permissive electoral laws) for the center-periphery cleavage to re-emerge on the issue of the extent of autonomy desirable for each region (or, in the case of Northern Ireland, to which nation-state the province should properly be attached). As a result of this confluence of factors, the party systems in the devolved areas are more complex bargaining environments than those found at the national level. In addition, the sub-national institutions create new challenges for the individual political parties, a subject to which we now turn.

\section{Parties in the Devolved Environments}

As noted above, Pedersen (1979) points to the level of party organization as an important issue in party system analysis. With regard to devolution 
in the UK, it would be reasonable to argue that the advent of new institutions at the sub-national level could create tension within the nationally based parties - Labour, Conservative and Liberal Democrats - as the regional wings of these parties diverge from the national platform. For example, the Conservatives were dead set against devolution, to the extent of actively campaigning against it in the referenda preceding the initiation of the plan. Once these referenda passed, the Tories were in the uncomfortable position of contesting seats for an institution they had fought against. Similarly, as region-specific issues conflict with those at the national level, disagreement becomes more likely.

To test this hypothesis, we rely on survey data gathered as part of a larger project. These surveys resulted in 75 responses from Members of the Scottish Parliament (MSPs) and 31 Members of the National Assembly for Wales (AMs) during 2000. ${ }^{6}$ We asked respondents whether they felt that devolution had increased, decreased or had no effect on tension within the party. The combined results from this question are displayed in Table 7 . The results show that nearly half of all Welsh AMs and over 40 percent of MSPs felt that devolution was associated with higher levels of tension within their party, while comparatively few felt that devolution had decreased tension within the party.

Table 8 breaks these results down by party and shows that in nearly all cases at least a plurality from each party associated devolution with increased party tension. The exceptions are the nationalist Plaid Cymru in Wales and the Scottish Conservatives. Although the small number of respondents necessitates caution, it is interesting to note that both Labour and the Liberal Democrats indicated increased tension. For Labour, this may result from controlling the House of Commons and being members of the executive in both Scotland and Wales. The Liberal Democrats' position is likely a reflection of being a junior partner in the coalition in place in Scotland. In addition, the Welsh Liberal Democrats were in the process at

Table 7. Survey results of MSPs and AMs on the effects of devolution on tension in party

Has development of a Scottish Parliament/National Assembly led to increased tension within your party?

$\begin{array}{lll}\text { The National Assembly/ } & \text { Wales } & \text { Scotland } \\ \begin{array}{l}\text { Parliament has increased tension } \\ \text { within the party }\end{array} & 48.39 \% & 40 \% \\ \begin{array}{l}\text { The National Assembly/ } \\ \text { Parliament has had no effect on }\end{array} & 38.71 \% & (\mathrm{~N}=18) \\ \begin{array}{l}\text { party tension } \\ \text { The National Assembly/ }\end{array} & (\mathrm{N}=12) & 42.2 \% \\ \begin{array}{l}\text { Parliament has decreased tension } \\ \text { within the party }\end{array} & 12.90 \% & 17.78 \% \\ & (\mathrm{~N}=4) & (\mathrm{N}=8)\end{array}$


Table 8. Survey results of MSPs and AMs on the effects of devolution on tension in party - by party

\begin{tabular}{llllllll}
\hline & W.Lab & S.Lab & PC & W.LD & S.LD & W.Con & S.Con \\
\hline Increased & $50 \%$ & $46.15 \%$ & $33.33 \%$ & $60 \%$ & $66.67 \%$ & $75 \%$ & $14.29 \%$ \\
& $(\mathrm{~N}=5)$ & $(\mathrm{N}=12)$ & $(\mathrm{N}=4)$ & $(\mathrm{N}=3)$ & $(\mathrm{N}=4)$ & $(\mathrm{N}=3)$ & $(\mathrm{N}=2)$ \\
\multirow{5}{*}{ No effect } & $40 \%$ & $38.46 \%$ & $41.67 \%$ & $40 \%$ & $33.33 \%$ & $25 \%$ & $50 \%$ \\
& $(\mathrm{~N}=4)$ & $(\mathrm{N}=10)$ & $(\mathrm{N}=5)$ & $(\mathrm{N}=2)$ & $(\mathrm{N}=2)$ & $(\mathrm{N}=1)$ & $(\mathrm{N}=7)$ \\
Decreased & $10 \%$ & $15.38 \%$ & $25 \%$ & $0 \%$ & $0 \%$ & $0 \%$ & $28.57 \%$ \\
& $(\mathrm{~N}=1)$ & $(\mathrm{N}=4)$ & $(\mathrm{N}=3)$ & $(\mathrm{N}=0)$ & $(\mathrm{N}=0)$ & $(\mathrm{N}=0)$ & $(\mathrm{N}=4)$ \\
\hline
\end{tabular}

the time of the survey (fall 2000) of joining Welsh Labour in coalition. Given that the last peacetime coalition in Britain occurred in the era of Lloyd-George, it is not surprising that this unfamiliar setting could cause tension.

Since these surveys were conducted one year after the initiation of devolved institutions in Wales and Scotland, they are limited in their application. Yet it is safe to conclude that at least initially devolution led to something of an increase in tension within political parties. Whether this will subside or increase is an open question, but these results also lead us to link the tension to the increased complexity of the party systems and in part to a divergence in how the sub-national assemblies are governed.

\section{Parties and Governments in the Devolved Settings}

As noted above, the devolved systems all diverged considerably from the British system in the area of government formation. Whereas single-party, majority government is the rule in the UK, in none of the three devolved systems did the election results allow this possibility. The increased number of political parties combined with the distribution of seats left parties with two options: govern alone as a minority government or form a coalition to obtain a majority. Interestingly, the three devolved systems initially followed different patterns of government formation.

Although diverse, a general principle of coalition theory is that parties will seek to minimize the distribution of power by creating bare minimumwinning options (for a review of coalition theory, see Lijphart, 1999). In Scotland, this was the course pursued by the Labour Party (the largest party) as it joined with the Liberal Democrats to form a minimum-winning coalition government. Labour also emerged as the largest party in Wales, but initially chose to form a minority government. In the fall of 2000, however, Labour and the Liberal Democrats mimicked the Scottish situation and joined in a minimum-winning coalition. In both of these situations the coalitions were not only minimum-winning, but also, in terms of policy 
positions, connected and of minimal range as the two parties are both relatively centrist. Under the Good Friday Agreement, the four main parties in Northern Ireland - two representing the Unionist position and two representing the Republican position - formed an oversized coalition government.

Additionally, nationalist parties emerged as the strongest members of the opposition in both Scotland and Wales. In the initial elections, the Welsh National Party, Plaid Cymru, received nearly 29 percent of the seats in the National Assembly, while the Scottish National Party (SNP) took 27 percent of the seats in parliament. As the largest non-executive parties, the SNP and Plaid Cymru formed the official opposition parties and set up shadow cabinets. Both nationalist parties retained their status in the second devolved elections, though both the SNP and, especially, Plaid Cymru, suffered losses of vote and seat shares in 2003.

Another difference between the devolved systems and the UK was displayed on the issue of the Poindings and Warrants bill in the Scottish Parliament. This bill, introduced by Scottish Socialist Tommy Sheridan as a private member's bill, called for an end to the practice of seizing and auctioning individuals' personal property to pay off debts. The Scottish Executive opposed the bill; however, Labour MSPs strongly supported it and voted en masse for its passage. This example diverges sharply from the practice of party politics in the House of Commons in two ways: first, private members' bills are uncommon at the UK level - almost all legislation emanates from the cabinet; second, anything opposed by the British cabinet has very little chance of passage (particularly if it originates from the opposition). As Alex Neil, an SNP member of both the Scottish Parliament and the House of Commons, put it 'something like that would never happen in Commons' (Interview conducted with Alex Neil, June 2000). Thus, the functioning of parties in Scotland varies a great deal from the British norm.

Hence, the increased complexity of the party systems in the devolved systems and the increased number of political parties led to coalition governments initially in two of the three systems, though the Welsh minority government followed suit in 2000. As a result, along with a general desire for more consensual arrangements, the executives do not have the same control over the assemblies, at least initially.

\section{Conclusions}

The devolution of authority to Scotland, Wales and Northern Ireland marked a fundamental shift in government in the UK. Not only was power decentralized, but also the sub-national bodies varied considerably from the UK level. In all three levels specified by Pedersen (1979) - the electoral, parties and governments and parties as organization - differences from the UK were observed. 
Based on the initial elections under devolution, several important patterns emerge with regard to the party systems in the devolved settings. First, the implementation of PR has led to larger party systems in the devolved institutions, both at the elective and parliamentary levels. While some of the differences between national and sub-national party systems may be due to the change in venue and different cleavage structures (e.g. the emergence of strong nationalist parties in both Scotland and Wales), there is a distinct, independent effect of the electoral rules. Additionally, the center-periphery cleavage has emerged in the devolved settings as more relevant than at the UK level. Even in Northern Ireland, where the republican-unionist divide already dominated, the cleavage has added importance as the pro- and antiagreement issues have divided parties in the system. Finally, the different contexts and electoral rules at the sub-national level have resulted in more complex, multiparty environments. Government formation diverges in all three devolved settings from the British norm of single-party majority government.

In closing, it is important to note that these results are preliminary - at the time of this writing less than five years have passed since the opening of the Scottish Parliament and Welsh Assembly - yet the distinctions from the national level are pronounced. Moreover, the 2003 devolved elections indicate that these differences are more than transitory.

\section{Notes}

We thank John Books, Alex Tan and two anonymous reviewers for their helpful comments on drafts of this article. A previous version was presented at the Conference on Parties and Elections in New Democracies, University of North Texas, 13 April 2002. Rob Bohrer thanks the Department of Political Science for general support and the Office of the Provost at Gettysburg College for a Research and Professional Development Grant provided for this study. Glen Krutz thanks the Arizona State University Office of the Vice-Provost for Research for a Faculty Grantin-Aid. Danielle Monacchi, Rebeca Hoeffer, Jessi Saracino and Michael Zaino provided research assistance.

1 Others found empirical support for the frozen party thesis as well (see Rose and Urwin, 1970).

2 The calculation of the effective number of parties was developed by Laakso and Taagepera (1979) and is simply as follows (effective number of elective parties) $E_{v}=1 / \Sigma v_{i}^{2}$, where $v_{i}$ is the vote share gained by each party in a given election. For the effective number of parliamentary parties, the calculation is the same except that seat shares for each party are substituted for vote shares.

3 For a more thorough analysis of the psychological and mechanical effects of the electoral laws in the devolved systems, see Bohrer and Krutz (forthcoming).

4 In the UK, this system is referred to as the Additional Member System (AMS), but we use the more general term of MMP. Similar systems are in place in Germany, Italy, New Zealand and Hungary. 
5 This is not to say that post-materialist cleavages are not influential in any way in the devolved settings, but rather that Green parties were largely absent in the initial elections. In Scotland, the SNP has a fairly active environmental agenda, and the prevalence of the center-periphery cleavage most likely masks the postmaterialist dimension.

6 Our overall response rate was 58.1 percent for the Scottish Parliament sample and 51.7 percent for the Welsh Assembly. The Scottish sample is reduced in this case, as the question was not asked of SNP members or the Green MSP.

\section{References}

Bartolini, Stefano and Peter Mair (1990) Identity, Competition, and Electoral Availability: The Stabilization of European Electorates, 1885-1995. Cambridge: Cambridge University Press.

Betz, Hans George (1993) 'The New Politics of Resentment: Radical Right-Wing Populist Parties in Western Europe', Comparative Politics 25: 413-25.

Blondel, Jean (1972) Comparing Political Systems. New York: Praeger.

Bohrer, Robert E., II (2001) Decision Costs and Democracy: Trade-Offs in Institutional Design. Aldershot: Ashgate.

Bohrer, Robert E., II and Glen S. Krutz (forthcoming) 'Duverger and Devolution: The Impact of Electoral Laws in the Devolved Systems of the United Kingdom', Electoral Studies.

Bohrer, Robert E., II and Alexander C. Tan (2000) 'Left Turn in Europe? Reactions to Austerity and EMU', Political Research Quarterly 53: 575-95.

Brown, Alice, David McCrone, Lindsay Paterson and Paula Surridge (1999) The Scottish Electorate: The 1997 General Election and Beyond. New York: St. Martin's Press.

Butler, David (1996) 'Great Britain and Northern Ireland', in Josep Colomer (ed.) Political Institutions in Europe. New York: Routledge.

Cox, Gary (1997) Making Votes Count: Strategic Coordination in the World's Electoral Systems. Cambridge: Cambridge University Press.

Dalton, Russell J. (1988) Citizen Politics in Western Democracies: Public Opinion and Political Parties in the United States, Great Britain, West Germany and France. Chatham, NJ: Chatham House Publishers.

Duverger, Maurice (1954) Political Parties. New York: John Wiley.

Ersson, Svante and Jan-Erik Lane (1998) 'Electoral Instability and Party System Change in Western Europe', in Paul Pennings and Jan-Erik Lane (eds) Comparing Party System Change, pp. 23-39. London: Routledge.

Hermens, F. A. (1941) Democracy or Anarchy? A Study of Proportional Representation. Notre Dame, IN: University of Notre Dame Press.

Inglehart, Ronald (1971) 'The Silent Revolution in Europe: Intergenerational Change in Post-Industrial Societies', American Political Science Review 65: 991-1017.

Inglehart, Ronald (1990) Cultural Change in Advanced Industrial Society. Princeton, NJ: Princeton University Press.

Interview with David McLetchie, Conservative MSP and Parliamentary Party Leader. Conducted by the authors, June 2000. 
Interview with Alex Neil, Scottish Nationalist Party MSP and MP. Conducted by the authors, June 2000.

Kitschelt, Herbert (1997) 'European Party Systems: Continuity and Change', in Martin Rhodes, Paul Heywood and Vincent Wright (eds) Developments in West European Politics. New York: St. Martin's Press.

Laakso, Markku and Rein Taagepera (1979) " "Effective” Number of Parties: A Measure with Application to West Europe', Comparative Political Studies 12: 3-27.

Lijphart, Arend (1991) 'Constitutional Choices for New Democracies', Journal of Democracy 2: 72-84.

Lijphart, Arend (1994) Electoral Systems and Party Systems: A Study of TwentySeven Democracies 1945-1990. New York: Oxford University Press.

Lijphart, Arend (1999) Patterns of Democracy: Government Forms and Performance in Thirty-Six Countries. New Haven, CT: Yale University Press.

Lipset, Seymour M. and Stein Rokkan (1967) 'Cleavage Structures, Party Systems and Voter Alignments: An Introduction', in Seymour M. Lipset and Stein Rokkan (eds) Party Systems and Voter Alignments: Cross National Perspectives. New York: Free Press.

Lipson, Leslie (1959) 'Party Systems in the United Kingdom and the Older Commonwealth: Causes, Resemblances and Variations', Political Studies.

Luebbert, Gregory M. (1991) Liberalism, Fascism, or Social Democracy: Social Classes and the Political Origins of Regimes in Interwar Europe. New York: Oxford University Press.

Mair, Peter (1997) Party System Change: Approaches and Interpretations. New York: Oxford University Press.

March, James G. and Johan P. Olsen (1984) 'The New Institutionalism: Organizational Factors in Political Life', American Political Science Review 78: 734-49.

McAllister, I. and Richard Rose (1984) The Nationwide Competition for Votes. London: Frances Pinter.

Ordeshook, Peter and Olga Shvetsova (1994) 'Ethnic Heterogeneity, District Magnitude and the Number of Parties', American Journal of Political Science 38: 100-23.

Pedersen, Mogens (1979) 'The Dynamics of European Party Systems: Changing Patterns of Electoral Volatility', European Journal of Political Research 7: 1-26.

Rae, Douglas W. (1967) The Political Consequences of Electoral Laws. New Haven, CT: Yale University Press.

Riker, W. (1982) 'The Two-Party System and Duverger's Law: An Essay on the History of Political Science', American Political Science Review 76: 753-66.

Rose, Richard and Derek Urwin (1970) 'Persistence and Change in Western Party Systems since 1945', Political Studies 18: 287-319.

Sartori, Giovanni (1994) Comparative Constitutional Engineering: An Inquiry into Structures, Incentives and Outcomes. New York: New York University Press.

Schattschneider, Eric Elmer (1960) The Semi-Sovereign People: A Realist's View of Democracy in America. New York: Holt, Rinehart and Winston.

Shamir, Michal (1984) 'Are Western Party Systems “Frozen”?' Comparative Political Studies 17: 35-79.

Taagepera, Rein and Matthew S. Shugart (1989) Seats and Votes: The Effects and Determinants of Electoral Systems. New Haven, CT: Yale University Press. 


\section{Data Sources}

United Kingdom and Devolved Elections:

BBC Online: www.bbc.co.uk

www.alba.org.uk

ROBERT E. BOHRER II is Associate Professor of Political Science at Gettysburg College. Along with several journal articles on electoral rules, devolution and democratic institutions, he has published Decision Costs and Democracy (2001). His main research interests are in democratic institutional performance, women's representation and devolution.

ADDRESS: Department of Political Science, Gettysburg College, 300 N. Washington St., Gettysburg, PA 17325, USA. [email: rbohrer@gettysburg.edu]

GLEN S. KRUTZ is Associate Professor of Political Science at the University of Oklahoma. In addition to his interest in devolution, he has research interests and several journal articles concerning the relationship between institutional design and public policy outcomes and published Hitching a Ride (2001). Together with Bohrer, he is currently working on a project entitled 'Institutional Development and Change: Devolution in the UK'.

ADDRESS: Department of Political Science, The University of Oklahoma, 455 West Lindsay St., Norman, OK 73019, USA. [email: gkrutz@ou.edu] 